\title{
SNOW ACCUMULATION AT "BYRD” STATION, ANTARCTICA
}

\author{
By A. J. Gow, \\ (U.S. Army Cold Regions Research and Engineering Laboratory, \\ Hanover, New Hampshire 03755, U.S.A.) \\ F. de Blander, G. Crozaz* and E. Picciotto \\ (Service de Géologie et Géochimie Nucléaires, Université Libre \\ de Bruxelles, Bruxelles, Belgium)
}

\begin{abstract}
The rate of snow accumulation at "Byrd" station, Antarctica, was measured by various methods. Surface measurements yield a mean accumulation of ${ }_{1} 17 \mathrm{~kg} \mathrm{~m}^{-2}$ year-1 for the time interval $1962-70$, within a $10 \mathrm{~m}$ radius of the station. The distribution of fission products with depth indicates a rate of $67 \pm 4 \mathrm{~kg} \mathrm{~m}^{-2}$ year $^{-1}$ for the period $1955^{-68}$ and of $100 \pm 10 \mathrm{~kg} \mathrm{~m}^{-2}$ year-1 for the period $1965^{-68}$. The ${ }^{210} \mathrm{~Pb}$ method yields a 60 year average of $\mathrm{I} 10 \pm 10 \mathrm{~kg} \mathrm{~m}^{-2}$ year-1.
\end{abstract}

RÉsumé. L'accumulation de la neige à "Byrd" station, Antarctique. Le taux d'accumulation de la neige à "Byrd"' station, Antarctique, a été mesuré par diverses méthodes. Les mesures de surface fournissent une accumulation moyenne de $117 \mathrm{~kg} \mathrm{~m}^{-2} \mathrm{a}^{-1}$ pour la période $1962-70$, dans un rayon de $10 \mathrm{~km}$ autour de la station. La distribution des produits de fission en fonction de la profondeur indique des valeurs de $67 \pm 4$ $\mathrm{kg} \mathrm{m}^{-2} \mathrm{a}^{-1}$ pour la période $1955-68$ et $100 \pm 10 \mathrm{~kg} \mathrm{~m}^{-2} \mathrm{a}^{-1}$ pour la période $\mathrm{I}^{6} 5_{5}^{-68}$. La méthode du $2 \mathrm{IoPb}$ donne une accumulation moyenne, sur les 60 dernières années, de $\mathrm{I} 10 \pm 10 \mathrm{~kg} \mathrm{~m}^{-2} \mathrm{a}^{-1}$.

Zusammenfassung. Die Schneeakkumulation an der "Byrd"-Station, Antarktika. Die Schneeakkumulation an der "Byrd"-Station, Antarktika, wurde nach verschiedenen Methoden gemessen. Messungen an der Oberfläche ergeben eine mittlere Akkumulation von $117 \mathrm{~kg} \mathrm{~m}^{-2} \mathrm{a}^{-1}$ für die Zeitspanne $1962-70$ innerhalb eines Kreises von $10 \mathrm{~km}$ Radius um die Station. Die Verteilung von Spaltprodukten in Abhängigkeit von der Tiefe führt zu einem Betrag von $67 \pm 4 \mathrm{~kg} \mathrm{~m}^{-2} \mathrm{a}^{-1}$ für die Zeit $1955^{-68}$ und von $100 \pm 10 \mathrm{~kg} \mathrm{~m}^{-2} \mathrm{a}^{-1}$ für die Zeit $1965-68$. Die ${ }^{210} \mathrm{~Pb}-$ Methode ergibt über 60 Jahre ein Mittel von $110 \pm 10 \mathrm{~kg} \mathrm{~m}^{-2} \mathrm{a}^{-1}$.

\section{INTRODUCTION}

The purpose of this study is to estimate the snow accumulation rate at "Byrd" station, at the location of the first core hole to bedrock in Antarctica (Gow and others, I968).

This knowledge, together with that of dynamic factors, is essential to the establishment of a time scale most useful for the interpretation of the data obtained by other investigators.

We report here the results obtained by surface measurements and by two radiometric methods based respectively on the distribution of the fission products and of ${ }^{210} \mathrm{~Pb}$ with depth in the firn.

\section{Surface MEASUREMENTS}

Two ro km long accumulation stake lines were established in February ig62 and have been monitored each year since. One line was oriented in an east-west direction, the other in a north-south direction (Fig. I); measurements at these stakes have provided the most reliable record of accumulation variations within a $10 \mathrm{~km}$ radius of "Byrd" station.

Results of the first 3 years' observations (Gow and Rowland, r965) indicated a strong topographic control on accumulation rates which all subsequent measurements continue to reflect, namely, that surface depressions accumulate appreciably more snow than the exposed ridges or crests. These relationships are clearly demonstrated in Figure 2, depicting measurements from the east-west line.

Snow stakes were originally emplaced on 16 February 1962, the distance between stakes being set at $0.5 \mathrm{~km}$. A total of 43 stakes was planted but records are incomplete at two

* Chargé de Recherches du Fonds National Belge de la Recherche Scientifique. 


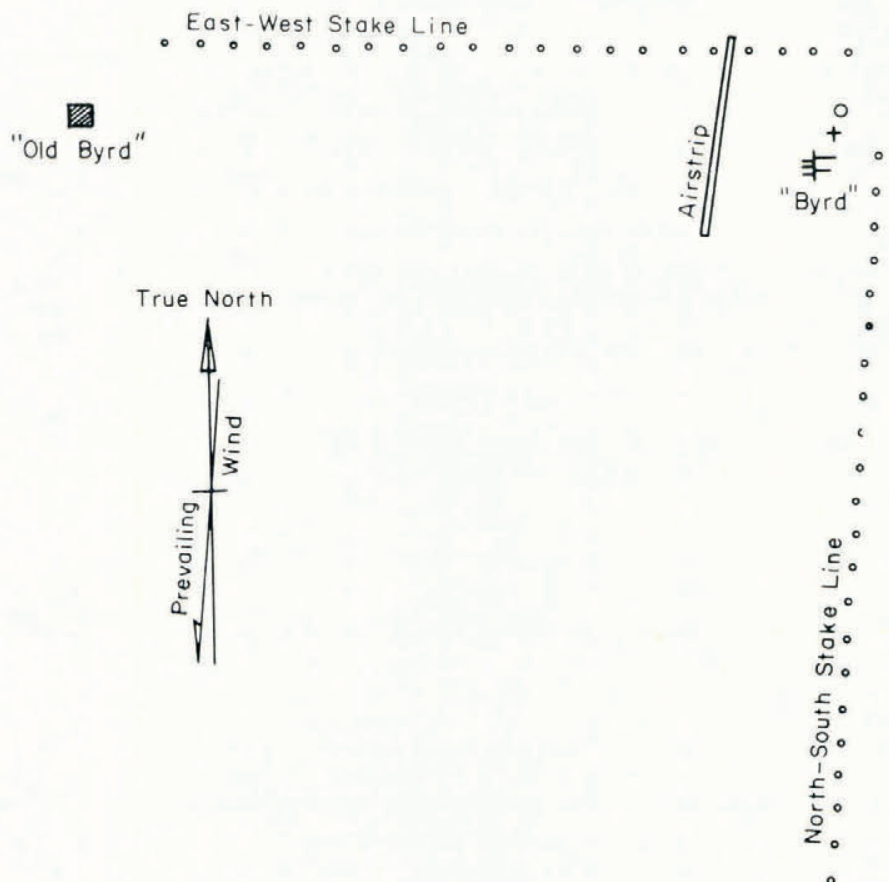

Fig. I. Sketch map of "Byrd" station and environs showing locations of accumulation stake lines and radiometric sampling sites. Spacing between accumulation stakes is approximately $0.5 \mathrm{~km}$. Location of samples used in this study is shown by a cross. Windom's (1969) sampling site is indicated by a circle.

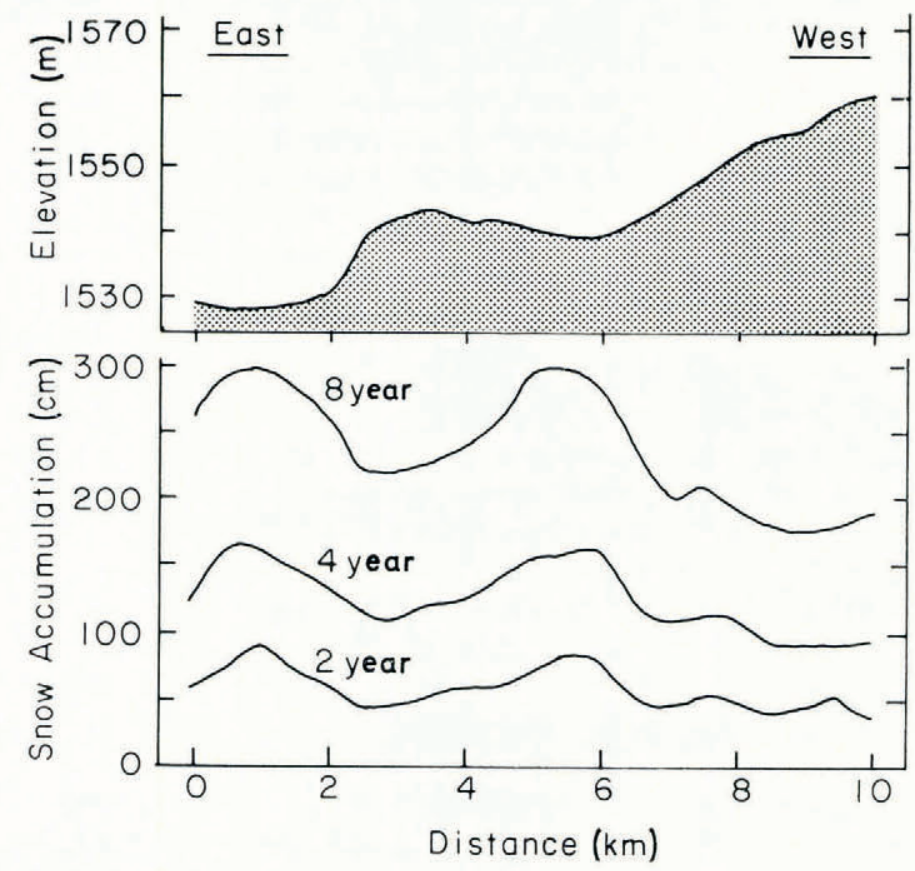

Fig. 2. Relationship of snow accumulation to undulating surface topography along the east-west stake line at "Byrd" station Antarctica. Surface depressions are accumulating 30-50\% more snow than the exposed crests. 
stakes. Snow accumulation at $4 \mathrm{I}$ stakes for the past 8 years has averaged $\mathrm{I}$ i $7 \mathrm{~kg} \mathrm{~m}^{-2}$ year-1. The stake showing the greatest accumulation in 8 years averaged $\mathrm{I} 57 \mathrm{~kg} \mathrm{~m}^{-2}$ year-1; that with the least accumulation averaged $86 \mathrm{~kg} \mathrm{~m}^{-2}$ year $^{-1}$. The largest accumulation recorded at any one stake in a given accumulation year (February to February) was $195 \mathrm{~kg} \mathrm{~m}^{-2}$ year-1.

Measurements made by R. L. Cameron (personal communication) at Ioo snow stakes, laid out in a $\mathrm{I} \mathrm{km}$ grid near the eastern corner of the east-west line, have yielded an average accumulation of $103 \mathrm{~kg} \mathrm{~m}^{-2}$ year -1 based on 2 years' measurements.

\section{FISSION PRODUCTS DISTRIBUTION IN THE FIRN}

The observation, by Picciotto and Wilgain ( 1963 ) and Vickers ( 1963 ), that a well-defined reference level in the upper layers of the Antarctic ice sheet has been formed by the stratospheric fall-out of radioactive debris released from the first large thermonuclear bomb test has provided a criterion for measuring the average accumulation rate since I955. This I955 horizon (Wilgain and others, I965), easily identified by a sudden and large increase in ${ }^{90} \mathrm{Sr}$ or in gross $\beta$ activity, has been used systematically to estimate snow accumulation rates at 75 stations on the east Antarctic plateau (Picciotto and others, in press).

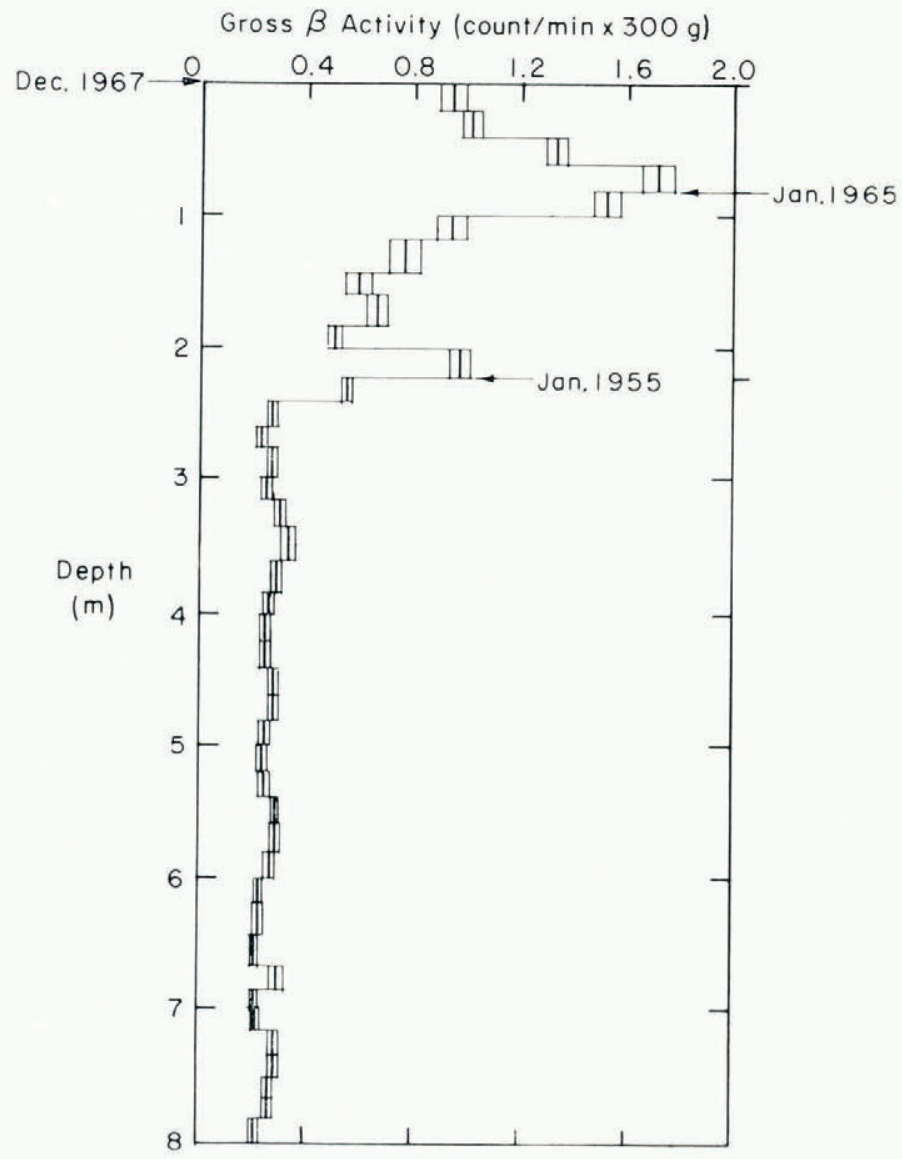

Fig. 3. Gross $\beta$ activity in the firn at "Byrd" station. The $\beta$ activity is expressed in counts per minute and per $300 \mathrm{~g}$ sample, without background correction. The error interval represents the standard deviation on the number of counts. The arrows show the positions of the $\beta$-activity maxima attributed respectively to January 1.955 and Famuary 1965 . 
An additional reference level, in January 1965 , corresponding to the fall-out of the atmospheric thermonuclear bombs detonated in 1962 has been recognized by Crozaz ( 1969 ).

The firn analysed here was collected in December 1967 near the northern corner of the north-south line. Five bulk samples were used for the depth interval from o to $\mathrm{I} \mathrm{m}$, and seven I $\mathrm{m}$ cores $(7.6 \mathrm{~cm}$ diameter hand-augered cores) from $\mathrm{I} \mathrm{m}$ down to $8 \mathrm{~m}$. Each core was cut in five pieces and $300 \mathrm{~g}$ samples were treated. The samples were kept frozen until analysed. The gross $\beta$ activity was measured after coprecipitation of the fission products with suitable carriers (see Picciotto and others, in press).

The distribution of the gross $\beta$ activity with depth is shown in Figure 3. The interpretation of these data is straightforward; the low, almost constant, activity below $240 \mathrm{~cm}$ is essentially due to the detector background and partially to the natural activity of ${ }^{210} \mathrm{~Pb}$. The jump at $220 \pm \mathrm{IO} \mathrm{cm}$ is attributed to the January $\mathrm{I} 955$ ( $\pm \mathrm{I}$ month) precipitations; above this level the usual decrease in activity is followed by a second important increase which culminates in January 1965 , at $80 \pm 10 \mathrm{~cm}$.

The resulting mean accumulation rates are $67 \pm 4 \mathrm{~kg} \mathrm{~m}^{-2}$ year-1 for the time period I $955^{-68}$ and $\mathrm{IOO} \pm \mathrm{I} \mathrm{kg} \mathrm{m}^{-2}$ year $^{-1}$ for $\mathrm{I} 965^{-68}$. The errors on the accumulation rates include the uncertainties on the $\beta$ surges, due to the finite thickness of the samples and the uncertainty on the time of occurrence of the respective horizons ( $\pm \mathrm{I}$ month).

TABLE I. "BYRD" STATION- ${ }^{218} \mathrm{~Pb}$ IN FIRN SAMPLES

\begin{tabular}{|c|c|c|c|}
\hline $\begin{array}{c}\text { Depth interval } \\
\mathrm{m}\end{array}$ & $\frac{{ }^{210} \mathrm{Po}}{{ }^{208} \mathrm{Po}}$ & $\begin{array}{l}\frac{{ }^{210} \mathrm{Po}}{{ }^{208} \mathrm{Po}} \\
\text { corrected }\end{array}$ & $\begin{array}{c}\text { Middle of depth } \\
\text { interval } \\
\mathrm{m}\end{array}$ \\
\hline $0-2$ & $1.04 \pm 0.04$ & $0.93 \pm 0.04$ & $0.3^{8}$ \\
\hline $2-4$ & $0.87 \pm 0.03$ & $0.76 \pm 0.03$ & I. 25 \\
\hline $4^{-6}$ & $0.82 \pm 0.03$ & $0.71 \pm 0.03$ & 2.16 \\
\hline $7-9$ & $0.4^{8} \pm 0.02$ & $0.37 \pm 0.02$ & 3.69 \\
\hline $9^{-10}$ & $0.49 \pm 0.02$ & $0.3^{8} \pm 0.02$ & 4.49 \\
\hline $9.68-10.64$ & $0.40 \pm 0.0 \mathrm{I}$ & $0.29 \pm 0.01$ & 4.76 \\
\hline $43 \cdot 3^{6-44.01}$ & $0.1 \mathrm{I} \pm 0.0 \mathrm{I}$ & - & - \\
\hline
\end{tabular}

The ${ }^{210} \mathrm{~Pb}$ relative activities are expressed in ${ }^{210} \mathrm{Po} /{ }^{208} \mathrm{Po}$ activity ratios. From a rough evaluation of the counting efficiency, a ${ }^{210} \mathrm{Po} /{ }^{208} \mathrm{Po}$ ratio of one corresponds to an absolute ${ }^{210} \mathrm{~Pb}$ activity of about 0.8 destint. $\mathrm{min}^{-1} \mathrm{~kg}^{-1}$.

${ }^{210} \mathrm{~Pb}$

The ${ }^{210} \mathrm{~Pb}$ method (Goldberg, 1963; Crozaz and others, I964) is based on the radioactive decay of the ${ }^{210} \mathrm{~Pb}$ occurring naturally in the atmosphere as a decay product of ${ }^{222} \mathrm{Ra}$. Its 22 year half life allows dating of firn samples up to ioo years old. This method has previously been applied at "Byrd" station by Windom (I969), who derived a mean accumulation rate of $98 \mathrm{~kg} \mathrm{~m}^{-2}$ year $^{-1}$.

The ${ }^{210} \mathrm{~Pb}$ activity as a function of depth was measured on hand-drilled cores from the same location, from the surface down to $10 \mathrm{~m}$. Two additional $\mathrm{i} 6 \mathrm{~cm}$ diameter cores (covering the depth intervals $9.68-10.64 \mathrm{~m}$ and $43.3^{6-44.01 ~} \mathrm{~m}$ ) were obtained from the deep drill hole at "Byrd" station.

The radiochemical procedure has been described in Crozaz and Fabri ( I 966) and Picciotto and others (in press). It is based on the $\alpha$ counting of ${ }^{210} \mathrm{Po}$ in equilibrium with ${ }^{210} \mathrm{~Pb}$. The chemical recovery yield is controlled by the use of a ${ }^{208} \mathrm{Po}$ tracer.

The concentrations of ${ }^{210} \mathrm{Po}$ as a function of the depth in water equivalent are shown in Table I. The results are expressed in ${ }^{210} \mathrm{Po} /{ }^{208} \mathrm{Po}$ activity ratios; the activities measured are taken to represent the activity at the middle of the depth interval covered by each sample.

A blank correction was applied by subtracting the activity found in the deepest sample, from 43.36 to $44.0 \mathrm{I} \mathrm{m}$ (which is more than 200 years old). 
From the slope of the best straight-line fit through the corrected values (Fig. 4) an accumulation rate of $120 \pm 10 \mathrm{~kg} \mathrm{~m}^{-2}$ year-1, averaged over the last 50 years, is deduced.

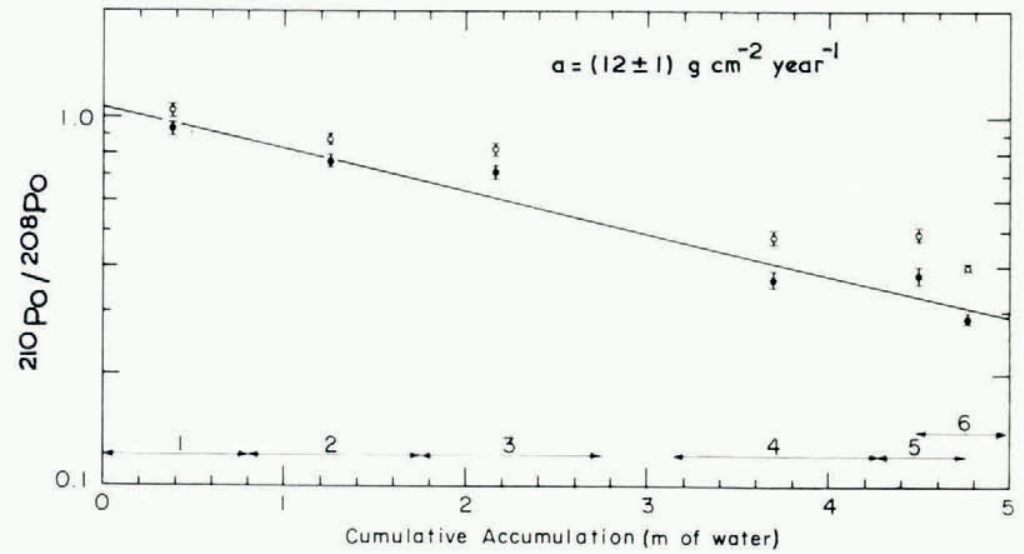

Fig. 4. Variation of the ${ }^{210} \mathrm{~Pb}$ activity in the firn as a function of depth in water equivalent. ${ }^{210} \mathrm{~Pb}$ activities are expressed relatively to the activity of the ${ }^{208} \mathrm{Po}$ tracer. Open circles represent uncorrected activity ratios. Dots represent activity ratios corrected for background. Error bars indicate the uncertainty due to counting statistics.

\section{Conclusion}

The results are summarized in Table II.

Consideration of surface stake measurements indicates that the average snow accumulation for the time interval $1962-70$, within a $10 \mathrm{~km}$ radius of "Byrd" station, varies from 86 to I $57 \mathrm{~kg} \mathrm{~m}^{-2}$ year $^{-1}$ with a mean value of 1 i $7 \mathrm{~kg} \mathrm{~m}^{-2}$ year ${ }^{-1}$.

Table II. Estimates of the annual accumulation at "Byrd" station

\begin{tabular}{|c|c|c|c|}
\hline $\begin{array}{c}\text { Annual interval } \\
\quad(\text { estimated })\end{array}$ & $\begin{array}{l}\text { Method of } \\
\text { measurement }\end{array}$ & $\begin{array}{l}\text { Accumulation } \\
\mathrm{kg} \mathrm{m}^{-2} \text { year }^{-\mathrm{I}}\end{array}$ & Reference \\
\hline 189o-I965 & ${ }^{210} \mathrm{~Pb}$ & 97 & Windom (r 969 ) \\
\hline $1964-65$ & Stakes & 103 & $\begin{array}{l}\text { R. L. Cameron (personal } \\
\text { communication) }\end{array}$ \\
\hline $1962-70$ & Stakes & 117 & Present work \\
\hline $1955-68$ & Fission products & $67 \pm 4$ & Present work \\
\hline $1965-68$ & Fission products & $100 \pm 10$ & Present work \\
\hline $1910-68$ & ${ }^{210} \mathrm{~Pb}$ & $120 \pm 10$ & Present work \\
\hline
\end{tabular}

The value for the time interval $1955^{-68}$, inferred from the fission products, is rather low but still compatible with the stake measurements since the cores used were from the same general area as the stakes with the lowest accumulation.

The accumulation derived from the ${ }^{210} \mathrm{~Pb}$ is in reasonable agreement with the one found by Windom at the same location. Combining both results, we conclude that the average accumu-

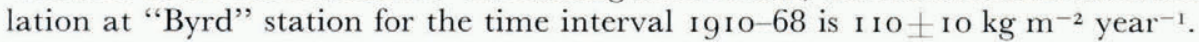

\section{AcKnowledgements}

The support of the Office of Antarctic Programs, National Science Foundation and of Task Force 43, U.S. Navy is gratefully acknowledged.

MS. received 23 August I97I 


\section{REFERENCES}

Crozaz, G. 1969. Fission products in Antarctic snow, an additional reference level in January 1965. Earth and Planetary Science Letters, Vol. 6, No. 1, p. 6-8.

Crozaz, G., and Fabri, P. 1966. Mesure du polonium à l'échelle de $1^{-13}$ curie traçage par le ${ }^{208} \mathrm{Po}$ et application à la chronologie des glaces. Earth and Planetary Science Letters, Vol. I, No. 6, p. 446-48.

Crozaz, G., and others. I964. Antarctic snow chronology with ${ }^{210} \mathrm{~Pb}$, by G. Crozaz, E. [E.] Picciotto and W. de Breuck. Fournal of Geophysical Research, Vol. 69, No. 12, p. 2597-604.

Goldberg, E. D. I963. Geochronology with lead-2 I0. (In Radioactive dating: proceedings of the symposium on radioactive dating held by the International Atomic Energy Agency in co-operation with the Joint Commission on Applied Radioactivity (ICSU) in Athens, 19-23 November 1962. Vienna, International Atomic Energy Agency, p. I2 I-3 I.)

Gow, A. J., and Rowland, R. 1965. On the relationship of snow accumulation to surface topography at "Byrd station", Antarctica. Fournal of Glaciology, Vol. 5, No. 42, p. 843-47.

Gow, A. J., and others. 1968. Antarctic ice sheet: preliminary results of first core hole to bedrock, [by] A. J. Gow, H. T. Ueda, D. E. Garfield. Science, Vol. 161, No. 3845, p. 10 I I-1 3 .

Picciotto, E. E., and Wilgain, S. E. 1963. Fission products in Antarctic snow: a reference level for measuring accumulation. Journal of Geophysical Research, Vol. 68, No. 21, p. 5965-72.

Picciotto, E. E., and others. In press. Accumulation along the South Pole-Queen Maud Land traverse, by E. [E.] Picciotto, G. Crozaz and W. de Breuck.

Vickers, W. W. 1963. Geochemical dating techniques applied to Antarctic snow samples. Union Géodésique et Géophysique Internationale. Association Internationale d'Hydrologie Scientifique. Assemblée générale de Berkeley, 19-8$31-81963$. Commission des Neiges et des Glaces, p. 199-2 15 .

Wilgain, S., and others. I965. Strontium go fallout in Antarctica, [by] S. Wilgain, E. [E.] Picciotto, W. de Breuck. Journal of Geophysical Research, Vol. 70, No. 24, p. 6023-32.

Windom, H. L. 1969. Atmospheric dust records in permanent snowfields: implications to marine sedimentation. Geological Society of America. Bulletin, Vol. 8o, No. 5, p. $76 \mathrm{I}_{-}-32$. 